\title{
Konseling Pendekatan Terapi Realitas untuk Mengatasi Prokrastinasi Akademik
}

\author{
Novia Solichah 1 \\ ${ }^{1}$ Fakultas Psikologi, UIN Maulana Malik Ibrahim Malang \\ DOI: http://doi.org/10.29080/jpp.v11i1.346
}

\begin{abstract}
Academic procrastination is characterized by an inability to manage time, determine priorities, and focus on the tasks they have, direct themselves and manage their actions so that many tasks are delayed. This study aims to determine the effectiveness of counseling with a reality therapy approach to overcome academic procrastination among college students. The emphasis of reality therapy is to make individuals responsible for an action selected. This quantitative experimental research uses a single case experiment design. Data collection was carried out through a series of assessments namely interviews, IST intelligence tests, graphic tests, EPPS, Informal Tests, and educational assessments. After having intervention, the subjects showed positive changes in finishing their work. On the other words, Counseling with a reality approach can help academic procrastination.
\end{abstract}

Keywords : Academic procrastination, Counseling, Reality therapy

\begin{abstract}
Abstrak : Prokrastinasi akademik ditandai dengan ketidakmampuan mengatur waktu, menentukan prioritas, fokus terhadap tugas yang dimiliki, mengarahkan diri dan mengatur tindakannya sehingga banyak tugas yang tertunda. Penelitian ini bertujuan untuk mengetahui efektifitas konseling dengan pendekatan terapi realitas untuk mengatasi prokrastinasi akademik pada mahasiswa. Penekanan terapi realitas adalah membuat individu bertanggung jawab atas tindakan yang dipilih. Penelitian kuantitatif eksperimental ini menggunakan single case experiment design. Pengumpulan data dilakukan melalui serangkaian asesmen yaitu wawancara, tes intelegensi IST, tes grafis, EPPS, Tes Informal, dan asesmen pendidikan. Setelah intervensi, subjek menunjukkan perubahan yang positif dalam pengerjaan tugas. Dengan kata lain, konseling dengan pendekatan realitas mampu membantu permasalahan prokrastinasi akademik.
\end{abstract}

Kata kunci : Prokrastinasi akademik, Konseling, Terapi realitas

\section{Pendahuluan}

Prokrastinasi merupakan respon menunda pengerjaan tugas dan dapat dipandang sebagai suatu trait (Knaus, 2010). Individu yang melakukan prokrastinasi cenderung 
menggunakan waktunya secara tidak efisien karena tidak segera mengerjakan tugas yang dihadapi (Ghufron, 2010). Bentuk penghindaran yang biasa dilakukan individu adalah menghabiskan waktu dengan teman atau pekerjaan lain yang sebenarnya tidak begitu penting daripada harus menyelesaikan apa yang seharusnya perlu dikerjakan terlebih dahulu (Akinsola, Tella \& Tella, 2007). Menurut Burka dan Yuen (2008) ada sejumlah ciri individu yang mengalami prokrastinasi yaitu memiliki ketidaksesuian antara rencana untuk melaksanakan tugas dengan perilaku yang dikerjakan, kemampuan rendah dalam merencanakan pelaksanaan tugas, serta kontrol diri yang rendah dalam melaksanakan aktivitas yang direncanakan.

Prokrastinasi yang terjadi pada area akademik disebut sebagai prokrastinasi akademik. Prokrastinasi akademik banyak dilakukan oleh pelajar dan mahasiswa. Mengerjakan tugas sekolah merupakan salah satu area akademik yang penting karena menjadi salah satu upaya tercapainya pemenuhan nilai akademik bagi siswa, namun hal ini tetap saja ditunda oleh kebanyakan siswa. Prokrastinasi akademik menurut Ferrari, Johnson \& McCown (1995) mengatakan bahwa suatu perilaku penundaan, prokrastinasi akademik dapat termanifestasikan dalam beberapa indikator tertentu yang dapat diukur dan diamati. Sejumlah ciri prokrastinasi berupa penundaan untuk memulai maupun menyelesaikan kerja pada tugas yang dihadapi, keterlambatan dalam mengerjakan tugas, kesenjangan waktu antara rencana dan kinerja, serta melakukan aktivitas lain daripada melakukan tugas yang harus dikerjakan.

Menurut Ferarri (1995) faktor yang dapat menyebabkan prokrastinasi akademik siswa meliputi faktor internal dan eksternal. Faktor internal, meliputi kondisi fisik, psikologis, self-regulation, takut gagal, tidak menyukai pekerjaan dan karena faktor lainnya. Kondisi fisik menggambarkan kondisi kesehatan individu seperti kelelahan yang tinggi cenderung membuat individu melakukan prokrastinasi (Ferarri, dkk, 1995). Faktor kedua adalah kondisi psikologis individu yaitu sifat yang mempengaruhi munculnya perilaku penundaan seperti rendahya kontrol diri, penghargaan diri, motivasi, perfeksionisme, dan tingkat kecemasan dalam hubungan sosial. Burka dan Yuen (2008) menegaskan bahwa self-regulation merupakan salah satu faktor yang mempengaruhi munculnya prokrastinasi pada peserta didik. Selanjutnya adalah takut gagal (fear of failure) yaitu kecenderungan akan mengalami rasa bersalah apabila tidak dapat mencapai tujuan atau gagal. Sikap tidak menyukai tugas berhubungan dengan perasaan negatif terhadap tugas seperti merasa dibebani tugas berlebihan, tidak puas, dan tidak senang menjalankan tugas yang diberikan. Selain itu ada beberapa faktor lainnya antara lain sifat ketergantungan pada orang lain, pengambilan resiko yang berlebihan, sikap kurang asertif, sikap memberontak, dan kesulitan membuat keputusan.

Selanjutnya ada sejumlah faktor eksternal yang terdapat di luar diri individu berupa pengasuhan orangtua dan lingkungan yang kondusif, yaitu lingkungan yang lenient. Pada kondisi lingkungan lenient, prokrastinasi akademik lebih banyak dilakukan pada lingkungan yang rendah dalam pengawasan daripada lingkungan yang penuh pengawasan (Rizvi, dkk, 1997). Ghufron (2010) menjelaskan bahwa prokrastinasi muncul tidak terlepas dari trauma masa kanak-kanak dan kesalahan dalam pengasuhan anak. Anak cenderung dituntut oleh orang tua dalam bidang apapun sehingga memunculkan kecemasan, kekhawatiran, dan ketidakberartian anak jika tidak bisa memenuhi harapan mereka. Kecemasan, kekhawatiran, dan ketidakberartian pada akhirnya memicu anak menunda- nunda melakukan pekerjaan. Hasil penelitian Ferrari dan Ollivete (Gufron, 2010) menemukan bahwa tingkat pengasuhan otoriter ayah menyebabkan munculnya kecenderungan perilaku prokrastinasi. Berbeda dengan pengasuhan otoriter, orangtua yang mendidik anaknya dengan demokratis akan menyebabkan timbulnya sikap asertif karena anak merasa diberi kebebasan dalam mengekspresikan diri sehingga memunculkan rasa percaya diri. 
Sejumlah penelitian mengatakan bahwa prokrastinasi sangat terkait dengan rendahnya tingkat keyakinan dan kepercayaan diri akademik serta tingginya kecemasan yang dimiliki (Cao, 2012). Terapi realitas adalah teknik konseling yang berorientasi pada tindakan membantu individu mengendalikan diri sendiri (Gladding, 2012). Menurut Corey (2000) dasar terapi realitas adalah membantu individu agar mampu menetapkan prioritas dan bertanggungjawab terhadap pilihan tindakan yang dilakukannya. Dalam proses konseling terapi realitas, individu dibantu untuk mengarahkan, melakukan monitoring, dan menilai dirinya serta bertanggung jawab terhadap tujuan yang ingin dicapai. Pada penelitian ini, peneliti fokus menangani prokrastinasi akademik yang dilihat sebagai kurangnya kinerja mandiri yang melibatkan aspek kognitif, aspek afektif, dan aspek perilaku (Cao, 2012).

Konseling dengan terapi realitas bertujuan untuk membantu individu menjadi rasional dan memiliki mental yang kuat (Gladding, 2012). Penekanan dari terapi realitas adalah bahwa setiap orang harus bertanggungjawab atas pilihan tindakan yang dilakukannya (Corey, 2009). Pada dasarnya, pendekatan ini menggunakan teknik yang berorientasi pada tindakan menyadarkan individu untuk memiliki pilihan dalam menanggapi berbagai peristiwa, tidak mengijinkan orang lain mengendalikan dirinya karena harus individu tersebut yang mengendalikan diri sendiri (Gladding, 2012)

Gladding (2012) menjelaskan bahwa pada pendekatan terapi realitas menggunakan system WDEP (Wants, Direction, Evaluation, Planning) sebagai metode dalam membantu konselor dan klien membuat kemajuan dan menerapkan teknik. Tahapan Wants dilakukan pada awal pelaksanaan konseling, dimana klien diajak untuk mengidenifikasi keinginan-keinginan apa yang ada dalam diri klien dan apa yang akan dilakukan (Gladding, 2012). Setelah berhasil mengidentifikasi keinginan klien, selanjutnya adalah tahap direction yang mengharuskan konselor menanyakan apa yang telah dilakukan klien sampa sejauh ini. Pada tahap ini klien diajak untuk melihat apakah tindakan yang sudah dilakukan telah mendekatkan klien dalam upaya mencapai keinginannya. Selanjutnya masuk ke tahap evaluation yaitu tahap membantu klien mengevaluasi perilaku mereka dan bagaimana merespon perilaku tersebut. Konselor bersama dengan klien melakukan analisa untuk melihat apakah yang dilakukan klien efektif untuk mencapai keinginannya. Terakhir adalah planning yaitu tahapan konselor mengajak klien untuk berfokus pada pembuatan rencana demi terjadinya perubahan perilaku. Rencana ini menekankan pada tindakan yang akan dilakukan oleh klien, bukan pada perilaku yang ingin dihilangkan. Rencana yang terbaik adalah rencana yang sederhana, dapat tercapai, terukur, segera, dan konsisten (Gladding, 2012).

\section{Metode Penelitian}

Penelitian ini merupakan penelitian eksperimen menggunakan single case experiment design dengan menggunakan satu kasus tunggal. Partisipan dalam studi ini adalah seorang mahasiswa fakultas psikologi di sebuah perguruan tinggi negeri di Surabaya. Untuk memperoleh diagnosis pada subjek yang dipilih, digunakan asesmen wawancara, skala self regulated learning, dan data sekunder yaitu kartu hasil studi. Disamping itu, dilakukan juga serangkaian tes intelegensi IST dan tes kepribadian formal, yaitu EPPS, Wartegg, dan Grafis (DAP, BAUM, dan HTP). Prosedur yang dilakukan dalam studi ini adalah pertama asesmen wawancara subjek terkait prokrastinasi akademik dan mengumpulkan data sekunder, kedua asesmen formal IST untuk mengetahui gambaran mengenai kemampuan intelektual subjek dalam proses belajar, ketiga asesmen kepribadian EPPS untuk mengetahui aspek kepribadian pada kebutuhan-kebutuhannya. Selanjutnya tahap keempat melakukan asesmen formal grafis dan wartegg untuk mengetahui aspek kepribadiannya secara menyeluruh, kelima pemberian skala self regulated learning, ketujuh membuat diagnosis permasalahan subjek, dan kedelapan 
memberikan perlakuan berupa konseling dengan pendekatan terapi realitas selama 9 sesi kepada subjek. Berikutnya peneliti melakukan monitoring perubahan perilaku subjek pada saat diberikan perlakuan dengan observasi dan wawancara serta melakukan evaluasi akhir dengan membandingkan sikap subjek dan tindakan terhadap penugasan kuliah, sebelum dan sesudah diberikan perlakuan. Teknik analisis dalam studi ini menggunakan metode analisis deskriptif komparatif yaitu tindakan subjek terhadap penugasan kuliah, sebelum dan sesudah perlakuan yang dijelaskan secara deskriptif.

Sebelum pemberian perlakuan, penulis menetapkan baseline perilaku subjek saat menerima penugasan kuliah dan selanjutnya membandingkan baseline perilaku dengan perilaku setelah intervensi. Perlakuan berupa konseling dengan pendekatan terapi realitas dan monitoring kemudian diberikan selama kurun waktu 3 minggu, kemudian dilakukan evaluasi dengan hasil monitoring program selama 1 minggu. Menurut Ghufron (2010) prokrastinasi adalah kecenderungan untuk tidak segera memulai pekerjaan ketika meghadapi suatu tugas. Bentuk penundaan yang dilakukan oleh subjek bukan hanya saat mengerjakan tugas, namun perilaku tersebut sudah terbiasa dilakukan oleh subjek sejak SMP. Subjek terbiasa dengan kebiasaan bila mengerjakan tugas dekat dengan tanggal pengumpulan tugas sehingga tugas yang dikerjakan menjadi tidak optimal. Bila dikaitkan denngan ciri-ciri orang yang mengalami prokrastinasi dengan perilaku subjek menurut Burka \& yuen (2008) adalah:

Tabel 1

Analisis Teoritik

\begin{tabular}{lll}
\hline \multicolumn{2}{c}{ Karakteristisk Prokrastinasi } & \multicolumn{1}{c}{ Keterangan } \\
\hline $\begin{array}{l}\text { Ketidaksesuian antara rencana } \\
\text { untuk melaksanakan tugas } \\
\text { dengan perilaku yang dikerjakan }\end{array}$ & $\begin{array}{l}\text { Pola belajar subjek ketika mengerjakan tugas adalah memulai } \\
\text { membuat rancangan dan berusaha memahami model } \\
\text { penugasannya. Namun ketika sudah memiliki rancangan subjek } \\
\text { melihat batas waktu pengumpulan. Muncul perasaan meremehkan } \\
\text { karena waktu pengumpulan masih lama muncul dan ada rasa } \\
\text { malas untuk mengerjakan. Pada akhirnya ia hanya punya waktu }\end{array}$ \\
& $\begin{array}{l}\text { sedikit dan hasilnya jauh dari standar yang diharapkan. Ketika } \\
\text { meninggalkan tugas, ia beralih pada aktivitas lain seperti main }\end{array}$ \\
& $\begin{array}{l}\text { gadget, menonton film, membaca komik, menonton youtube, main } \\
\text { game, olah raga, dan membersihkan kamar }\end{array}$ \\
\hline $\begin{array}{l}\text { Kemampuan rendah dalam } \\
\text { merencanakan pelaksanaan tugas }\end{array}$ & $\begin{array}{l}\text { Subjek sudah membuat rencana sebelum mengerjakan tugas, } \\
\text { namun jarang terealisasi apa yang telah dibuatny }\end{array}$ \\
\hline $\begin{array}{l}\text { Kontrol diri yang rendah dalam } \\
\text { melaksanakan aktivitas yang }\end{array}$ & $\begin{array}{l}\text { Subjek tidak dapat mengontrol diri untuk menghindari kegiatan } \\
\text { direncanakan }\end{array}$ \\
& yang tidak ada hubungannya dengan tugas. Subjek lebih memilih \\
beralih ke aktivitas yang lebih menyenangkan seperti main gadget, \\
menonton film, membaca komik, menonton youtube, main game, \\
olah raga, dan membersihkan kamar.
\end{tabular}

\section{Hasil Penelitian}

Konseling ini dilakukan berdasarkan prinsip WDEP (Wants, Direction, Evaluation, dan Planning). Berikut rincian hasil evaluasi pada tiap sesi konseling:

Tabel 2

Evaluasi Hasil Intervensi untuk Subjek

\begin{tabular}{|c|c|c|c|}
\hline Sesi & Tujuan Sesi & Kondisi Awal & Kondisi Akhir \\
\hline 3 & $\begin{array}{l}\text { 1. Subjek mampu } \\
\text { mengidentifikasi } \\
\text { segala potensi } \\
\text { dan kekurangan } \\
\text { yang dimiliki }\end{array}$ & $\begin{array}{l}\text { 1. Subjek belum dapat } \\
\text { mengidentifikasi potensi yang } \\
\text { dimiliki } \\
\text { 2. } \\
\text { subjek belum mengetahui } \\
\text { perilaku apa saja yang harus } \\
\text { dipersiapkan untuk mencapai } \\
\text { harapannya }\end{array}$ & $\begin{array}{l}\text { 1. Subjek dapat mengidentifikasi } \\
\text { segala potensi yang dimiliki } \\
\text { 2. Subjek mengetahui perilaku yang } \\
\text { harus dipersiapkan untuk } \\
\text { mencapai harapannya }\end{array}$ \\
\hline
\end{tabular}




\begin{tabular}{|c|c|c|c|c|}
\hline & 2. & $\begin{array}{l}\text { Subjek } \\
\text { mengetahui } \\
\text { perilaku yang } \\
\text { harus } \\
\text { dipersiapkan } \\
\text { dan dilakukan } \\
\text { untuk mencapai } \\
\text { harapannya }\end{array}$ & & \\
\hline $4 \& 5$ & 1. & $\begin{array}{l}\text { Subjek dapat } \\
\text { mengetahui } \\
\text { perilaku yang } \\
\text { mendekatkan } \\
\text { atau } \\
\text { menjauhkan dari } \\
\text { harapannya }\end{array}$ & $\begin{array}{l}\text { 1. Subjek belum pernah } \\
\text { melakukan evaluasi terhadap } \\
\text { apa saja yang telah dilakukan } \\
\text { selama ini terkait harapan } \\
\text { 2. Subjek belum mengenali } \\
\text { perilaku apa saja yag } \\
\text { mendekatkan dan menjauhkan } \\
\text { subjek pada harapannya }\end{array}$ & $\begin{array}{l}\text { 1. Subjek mampu mengevaluasi apa } \\
\text { yang dilakukan untuk mencapai } \\
\text { harapan } \\
\text { 2. Subjek mengenali perilaku yang } \\
\text { mendekatkan atau menjauhkan } \\
\text { dari harapannya }\end{array}$ \\
\hline $6 \& 7$ & 1. & $\begin{array}{l}\text { Subjek membuat } \\
\text { rencana baru } \\
\text { yang akan } \\
\text { dilakukannya } \\
\text { dan } \\
\text { berkomitmen } \\
\text { untuk } \\
\text { melakukannya } \\
\text { dengan encapai } \\
\text { harapan } \\
\text { tersebut }\end{array}$ & $\begin{array}{l}\text { 1. Subjek belum mempunyai } \\
\text { jadwal aktivitas dan } \\
\text { strateginya yang dapat } \\
\text { membantu subjek untuk } \\
\text { mencapai harapannya } \\
\text { 2. Subjek belum pernah } \\
\text { melakakan self monitoring } \\
\text { sebagai bagian dari teknik } \\
\text { regulasi diri }\end{array}$ & $\begin{array}{l}\text { 1. Subjek mempunyai jadwal } \\
\text { aktivitas dan strateginya yang } \\
\text { dapat membantu subjek untuk } \\
\text { mencapai harapannya } \\
\text { 2. Subjek melakukan self monitoring } \\
\text { sebagai bagian dari teknik } \\
\text { regulasi diri }\end{array}$ \\
\hline $8 \& 9$ & 1. & $\begin{array}{l}\text { Subjek } \\
\text { menjalankan } \\
\text { rencana yang } \\
\text { telah dibuat } \\
\text { pada sesi } \\
\text { sebelumnya dan } \\
\text { meninjau } \\
\text { efektivitas dari } \\
\text { rencana yang } \\
\text { telah dibuat } \\
\text { Mengakhiri sesi } \\
\text { konseling }\end{array}$ & $\begin{array}{l}\text { 1. Subjek menjalankan rencana } \\
\text { yang telah dibuat di sesi } \\
\text { sebelumnya } \\
\text { 2. Subjek merasa saat ini } \\
\text { hidupnya lebih teratur } \\
\text { sehingga harapan subjek yaitu } \\
\text { ingin mendapatkan hasil IPK } \\
\text { dan IPS yang memuaskan dapat } \\
\text { dicapai }\end{array}$ & $\begin{array}{l}\text { 1. Subjek berkomitmen untuk tetap } \\
\text { menjalankan rencana yang telah } \\
\text { dibuat } \\
\text { 2. Subjek merasakan bahwa } \\
\text { harapannya untuk mendapatkn } \\
\text { IPK dan IPS memuaskan semakin } \\
\text { terlihat dengan jelas }\end{array}$ \\
\hline
\end{tabular}

Selanjutnya adalah hasil Konseling dilakukan sebanyak 9 dan evaluasi dilakukan berdasarkan pencapaian subjek dengan melihat target perilaku dan kondisi akhir subjek.

Tabel 3

Evaluasi Sesi Pelaksanaan Intervensi

Sesi Evaluasi pelaksanaan intervensi

1 dan 2 1. Subjek mengetahui tujuan konseling

2. Subjek berkomitmen terhadap hasil yang disepakati dalam konseling, secara sadar ia menyampaikan kebutuhan konseling untuk membantunya menjadi lebih rajin dan mendapatkan IPK dan IPS yang memuaskan.

3. Subjek mengetahui, memahami dan dapat menyimpulkan dengan baik kelebihan dan kekurangan dirinya melalui hasil asesmen yang dijelaskan

4. Saat penjelasan hasil asesmen subjek beberapa kali bertanya jika ia merasa belum paham

5. Subjek memahami hambatan mendapatkan IPK di bawah 3,mengulang 2 mata kuliah dan belum mengambil beberapa mata kuliah akibat dari perilaku prokrastinasi

6. Subjek menyatakan bahwa ia masih belum fokus, kurang inisiatif dan tanggung jawab dalam mengerjakan tugas, kurang maksimal dalam belajar, sering melakukan hal tidak berhubungan dengan akademik, dan memiliki tanggung jawab mengasuh adik-adik.

7. Subjek mampu membuat daftar hal-hal yang diinginkan untuk dicapai dalam jangka panjang dan jangka pendek.

8. Subjek bersama konselor menentukan prioritas keinginan dari harapan atau tujuan jangka pendek yang ingin dicapai 
9. Konselor memperjelas prioritas keinginan atau harapan subjek untuk jangka pendek ini yaitu ingin menguasai materi perkuliahan, membuat buku catatan, mendapat nilai yang bagus dalam UTS, UAS, dan tugas, mendapat nilai yang memuaskan IPK dan IPS, mampu menyelesaikan tugas tepat waktu dan sesegera mungkin menyelesaikan tugas.

10. Subjek menyadari bahwa untuk mencapai harapan tersebut ia harus berubah menjadi rajin, mengerjakan tugas dan mampu mengarahkan dirinya untuk mencapai harapan.

3 1. Subjek mengidentifikasi segala potensi dan kekurangan yang dimiliki

2. Subjek mengenali sejumlah potensi yang mendukungnya untuk meraih tujuan

3. Subjek mengidentifikasi perilaku untuk mengarahkan dirinya pada penyelesaian tugas

4. Subjek mengetahui berbagai usaha yang mendekatkan dan menjauhkan pada harapan

4 dan 5 1. Subjek menyadari evaluasi yang dilakukan hanya dalam pikiran saja tanpa tindakan lebih lanjut sehingga subjek tidak mengetahui seberapa efektifkah usahayang dilakukannya

2. Subjek menyadari bahwa hambatan yang selama ini dirasakan berasal dari dirinya sendiri

3. Subjek mampu melakukan evaluasi atas apa saja yang telah dilakukan terkait harapannya

4. Subjek mampu mengidentifikasi perilaku mendekatkan dan menjauhkan dari harapan

5. Subjek merasakan ada semangat baru untuk merubah perilakunya, melakukan apa yang menjauhkan dan mendekatkan kepada harapan

6 dan 7 1. Subjek mulai bersemangat untuk mengubah perilakunya dan segera menghubungi temantemannya lagi untuk menanyakan tugas dan mulai belajar kelompok.

2. Subjek bercerita bahwa ia mulai bersemangat mengerjakan tugasnya

3. Subjek mampu membuat rencana serta strategi yang harus ia lakukan untuk mengejar nilai yang lebih baik, membuat konsekuensi atas perilakunya jika memenuhi atau tidak memenuhi rencana dan strategi yang dibuat

4. Subjek merasakan kemudahan dengan adanya rencana dan strategi yang dibuat sehingga mengetahui apa yang harus dilakukan terlebih dahulu serta tahapan mengerjakan tugas

8 dan 9 1. Subjek mulai mengerjakan tugas di awal waktu dan tidak menunda-nunda

2. Subjek mulai dapat melakukan evaluasi kegiatan yang telah dilakukan sehingga subjek mulai merasakan usaha yang membantunya mempercepat penyelesaian tugas

3. Subjek melakukan self monitoring

4. Subjek menyampaikan bahwa ia mulai dapat membuktikan sesuatu, akibat dari perilaku rajin belajar dan mencatat tiap tugasnya ia mendapatkan nilai kuis 2 kali 90, padahal biasanya subjek menyatakan jelek $(<50)$

5. Subjek tetap meminta praktikkan untuk memantau perkembangan tugasnya sehingga rencana jangka pendeknya terlaksana dengan baik

Berikut ini adalah sejumlah perubahan perilaku pada diri subjek adalah setelah dilakukan evaluasi berdasarkan hasil observasi dan wawancara dengan subjek dan temannya setelah konseling berakhir.

a. Subjek mulai membuat jadwal kegiatan dengan rinci karena itu membantunya mengerjakan tugas secara terarah.

b. Subjek berusaha menyalin catatan kembali serta melengkapi catatannya setiap hari

c. Subjek berusaha menyempatkan dua kali setiap minggu untuk belajar bersama temantemannya karena ia merasa mendapatkan banyak pengetahuan jika belajar bersama

d. Subjek mulai kembali mencari referensi yang dapat menunjang pengerjaan tugas dengan cara membuat ringkasan catatan dari buku milik teman, meminjam buku perpustakaan, membeli buku, ke ruang baca, serta ke perpustakaan pusat

e. Subjek makin sering mengunjungi perpustakaan dan berdiskusi dengan teman

f. Subjek lebih fokus pada mengerjakan tugas

g. Subjek mulai menjadwalkan tugas secara rutin sejak konseling sesi 8 dan 9 berakhir

h. Subjek membuat daftar pertanyaan hambatan ataupun sesuatu yang tidak dimengerti

i. Subjek menargetkan harus ada peningkatan nilai yang didapatkan, seperti nilai kuis dan UTS

j. Dosen wali subjek bersedia memantau perkembangan subjek

\section{Pembahasan}

Konseling dengan pendekatan terapi realitas yang berdasarkan prinsip WDEP (Wants, Direction, Evaluation, dan Planning) dapat membantu individu yang mengalami 
prokrastinasi akademik. Tahapan WDEP yang diterapkan peneliti menunjukkan hasil yang signifikan pada subjek. Pendekatan terapi realitas yang digunakan dalam konseling dilakukan sebanyak 9 sesi. Konseling dengan pendekatan terapi realitas ini juga mampu membantu subjek untuk mengarahkan diri, melakukan monitoring terhadap diri, menilai diri, serta bertanggung jawab dengan tujuan yang ingin dicapai.

Hasil evaluasi dari konseling menggunakan pendekatan terapi realitas ini nampak dari subjek yang bersedia untuk berkomitmen secara penuh untuk menjadi lebih rajin dari sebelumnya, kemudian subjek juga mengetahui, memahami dan dapat menyimpulkan dengan baik akan kelebihan dan kekurangan dalam dirinya. Subjek menyatakan bahwa ia masih belum fokus, inisiatif masih masih kurang dalam mengerjakan tugas, tanggung jawab untuk mengerjakan tugas kurang, belajar kurang maksimal, melakukan hal-hal yang tidak berhubungan dengan akademik, sehingga subjek mampu membuat daftar hal-hal yang diinginkannya untuk dicapai dalam jangka panjang dan jangka pendek. Subjek juga menyadari jika untuk mencapai harapan tersebut, ia harus berubah menjadi pribadi yang lebih rajin, terus mengerjakan tugas dan mampu mengarahkan dirinya untuk mencapai harapan tersebut.

Konseling dengan pendekatan terapi realitas dimana didalamnya ada tahapan WDEP (Wants, Direction, Evaluation, Planning) yang diterapkan peneliti menunjukkan hasil yang signifikan pada subjek. Subjek menyadari bahwa hambatan yang selama ini dirasakan oleh subjek mengenai penyelesaian tugas yaitu berasal dari dirinya sendiri. Subjek merasakan ada semangat baru untuk merubah perilakunya yang menjauhkan dari harapannya menjadi mendekatkan kepada harapannya. Subjek mampu membuat rencana-rencana serta strategi yang harus ia lakukan untuk mengejar nilai yang lebih baik, serta subjek mampu membuat konsekuensi atas perilakunya jika memenuhi atau tidak memenuhi rencana dan strategi yang ia buat sendiri. Subjek merasakan kemudahan dengan adanya rencana serta strategi yang dibuat oleh subjek, sehingga subjek mengetahui apa yang harus dilakukan terlebih dahulu serta tahap demi tahap dalam mengerjakan tugas. Subjek memulai mengerjakan tugas di awal waktu dan tidak di tunda-tunda. Subjek mulai dapat melakukan evaluasi kegiatan yang telah dilakukannya, sehingga subjek mulai merasakan usaha-usaha yang membantunya mempercepat penyelesaian tugas. Subjek mampu melakukan self monitoring. Subjek menyampaikan bahwa ia mulai dapat membuktikan sesuatu, akibat dari perilaku rajin belajar dan mencatat tiap tugasnya ia mendapatkan nilai kuis 2 kali 90, padahal biasanya subjek menyatakan jelek $(<50)$.

Berdasarkan hasil asesmen dan penyusunan rancangan intervensi pada subjek maka berikut beberapa hal yang dapat disarankan dan direkomendasikan penulis kepada subjek, yaitu:

1. Subjek terus menjaga semangatnya dalam mengerjakan tugas yang ada seperti saat menjalani sesi konseling, sehingga subjek dapat menyelesaikan tugas sesuai dengan target yang dibuat oleh subjek sendiri.

2. Subjek diharapkan mampu melakukan evaluasi terhadap segala aktivitas yang dilakukannya mengenai akibat dari kinerja yang telah dilakukan dalam proses pengerjaan tugas.

3. Subjek disarankan untuk menentukan setiap target-target yang ingin dicapainya dalam proses perkuliahan

4. Subjek berusaha menentukan strategi yang akan digunakannya dalam proses mencapai setiap target yang ingin dicapai

5. Subjek diharapkan untuk selalu mempersiapkan rencana alternatif dalam setiap aktivitas yang akan dijalani sebagai upaya mengatasi kendala dan memenuhi kebutuhan yang mungkin dihadapi dalam aktivitas perkuliahan

6. Subjek terus mempertahankan kebiasaan untuk pembuatan jadwal kegiatan yang berhubungan dengan pengerjaan tugas sehingga dapat menjadi panduan subjek saat mengerjakan tugasnya dan juga sebagai alat evaluasi dan self monitoring subjek.

7. Subjek lebih sering untuk melakukan diskusi dengan teman-teman yang sedang mengerjakan tugas ataupun teman subjek yang lain dan diskusi dengan dosen bila 
subjek mengalami kebingungan atau kesulitan selama mengerjakan tugas, sehingga subjek bisa mendapatkan solusi atas kesulitan atau kebingungan yang dihadapinya dengan cepat.

\section{Simpulan dan Saran}

Dari intervensi yang telah dilakukan, pada evaluasi berdasarkan hasil observasi dan wawancara setelah konseling, subjek menunjukkan perubahan yang positif dalam pengerjaan tugas. Oleh karena itu, dapat disimpulkan bahwa konseling menggunakan pendekatan terapi realitas mampu mengatasi prokrastinasi akademik, dan mampu membentuk perilaku yang lebih aktif pada saat menerima beberapa penugasan. Berdasarkan penelitian ini, maka disarankan agar konseling menggunakan pendekatan terapi realitas dapat menjadi salah satu cara media untuk mengatasi prokrastinasi akademik.

\section{Daftar Pustaka}

Akinsola, K. M., Tella, A. \& Tella, A. (2007). Correlates of academic procrastination and mathematics achievement of University Undergraduate Students, 3 (4), 363-370

Burka, J. B. \& Yuen, L.M. (2008). Procrastination: Why You Do it, What to do about it now. USA: Perseus Book Group.

Cao, L. (2012). Examining "active" Procrastination From A Self Regulated Learning Perspective: An International Journal of Experimental Educational Psychology. USA: University of West Georgia.fer

Corey, G. (2009). Theory and Practice of Counseling and Psychotherapy $8^{\text {th }}$ Edition. USA: Thomson Brooks/Cole.

Ferrari, J. R. Johnson, J.L. \& Mc Cown, W. G. (1995). Procrastination and Task Avoidance, Theory, Research and Treatment. New York: Pelnum Press

Ghufron. (2010). Teori-Teori Psikologi. Jogjakarta: Ar-Ruzz Media Group.

Gladding, S. T. (2012). Konseling: Profesi yang menyeluruh. Jakarta: Indeks

Knaus, W. (2010). End Procrastination Now! Get it Done With A Proven Psychological Approach. USA: The McGraw-Hill Companies.

Rizvi, A., Prawitasari., J.E., \& Soetijono, H. P. (1997). Pusat Kendali dan Efikasi diri sebagai predictor terhadap prokrastinasi akademik mahasiswa. Psikologika nomor 2 tahun 11, hal $51-66$ 